
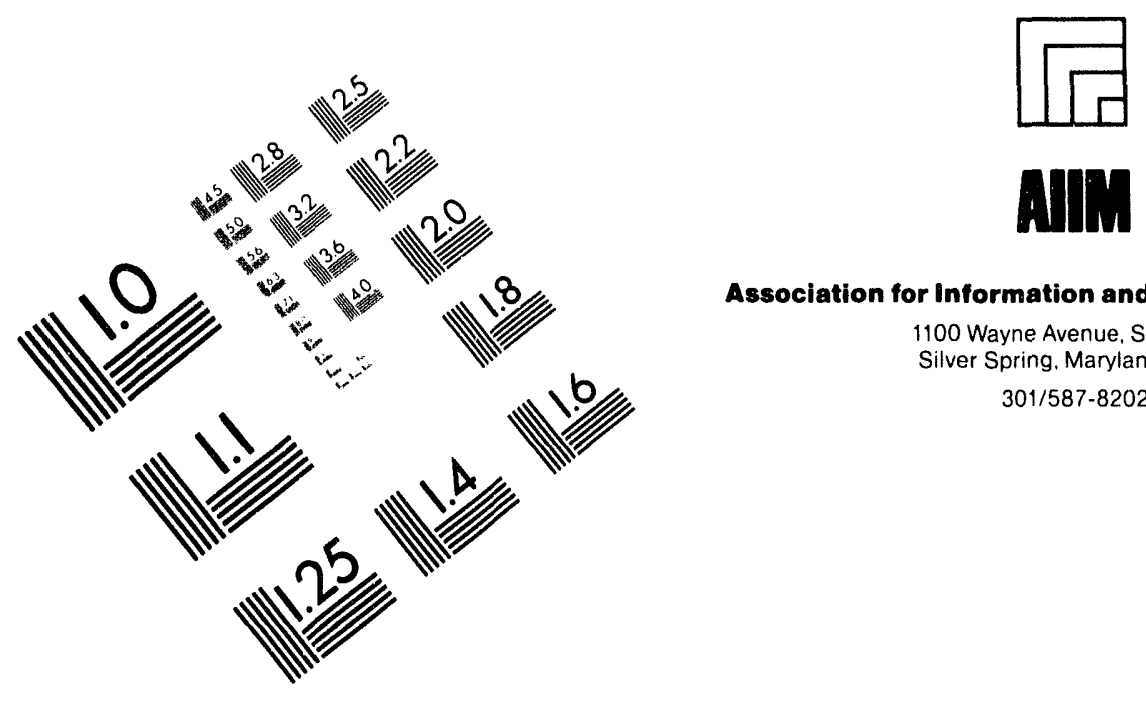

Association for Information and Image Management

1100 Wayne Avenue, Suite 1100

Silver Spring. Maryland 20910

301/587-8202

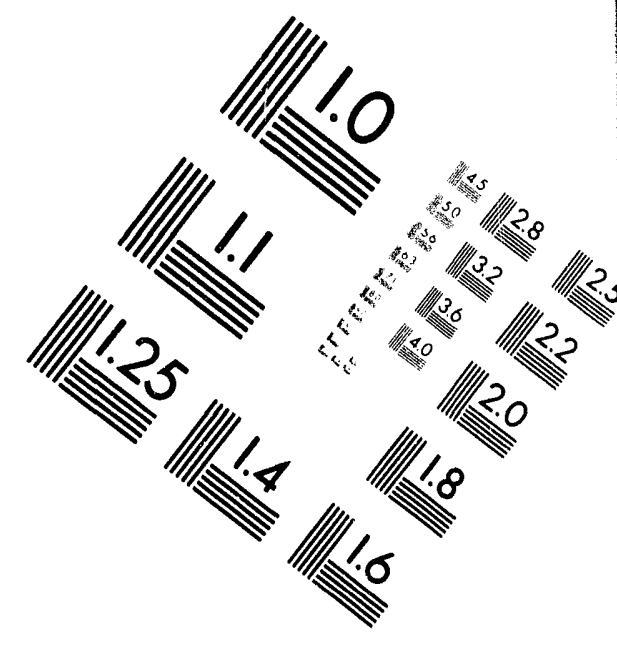

Centimeter

$\begin{array}{llllllllllllllll}1 & 2 & 3 & 4 & 5 & 6 & 7 & 8 & 9 & 10 & 11 & 12 & 13 & 14 & 15 & \mathrm{~mm}\end{array}$

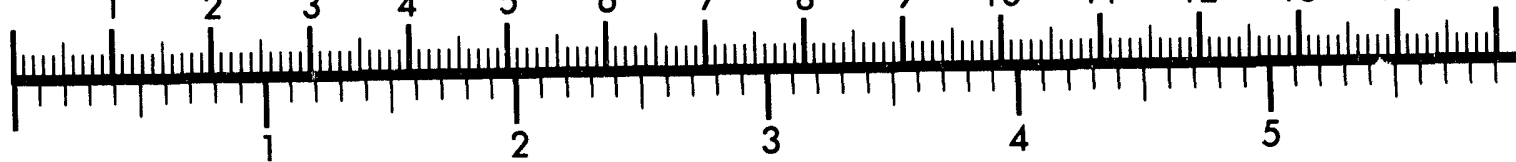
Inches
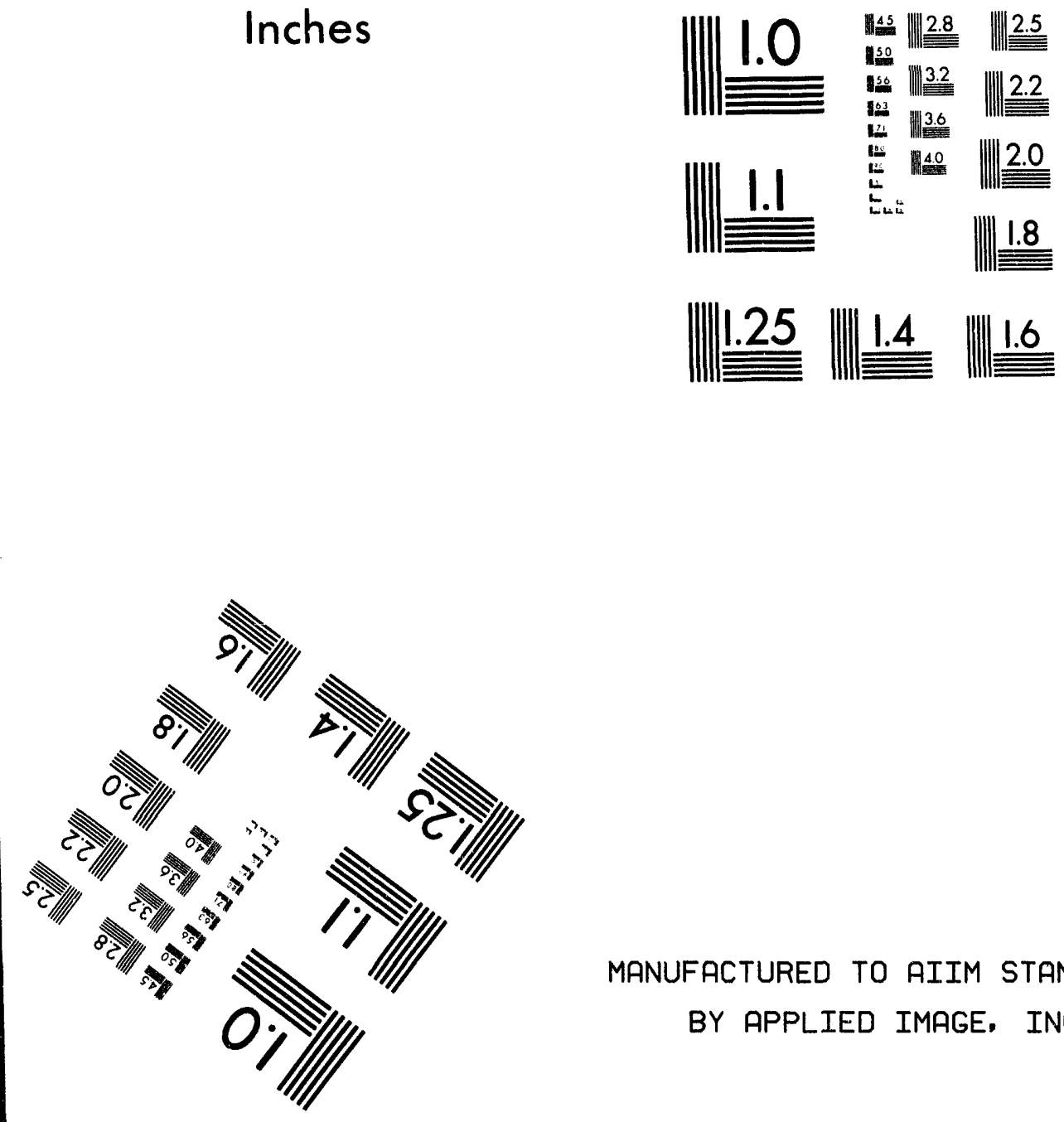

MANUFACTURED TO AIIM STANDARDS BY APPLIED IMAGE, INC.

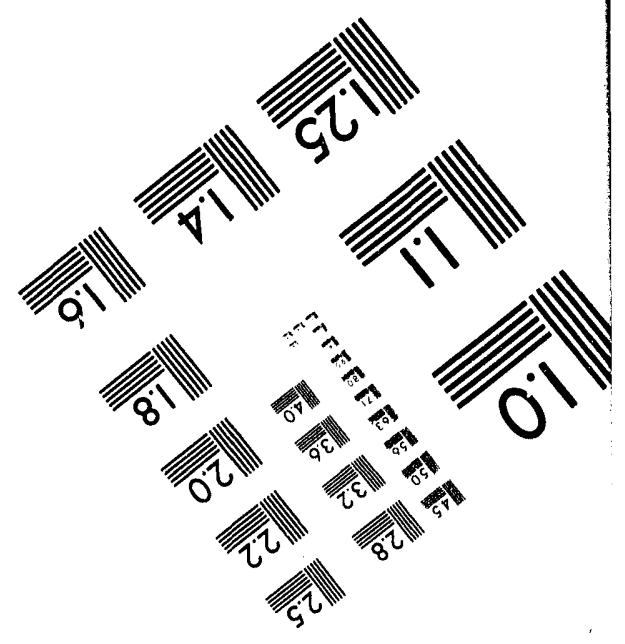



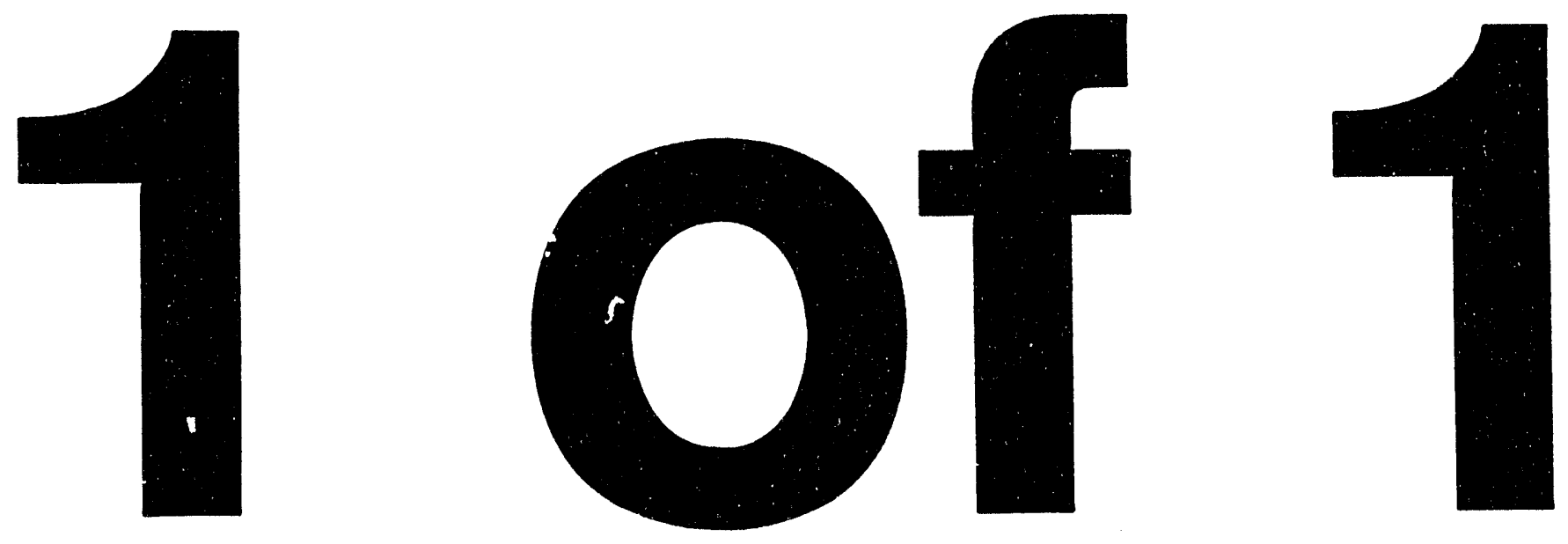


\section{AN AERIAL RADIOLOGICAL SURVEY OF THE FORT CALHOUN NUCLEAR POWER PLANT AND SURROUNDING AREA}

FORT CALHOUN, NEBRASKA

DATE OF SURVEY: JUNE 1993

K. A. McCall

Project Scientist

REVIEWED BY

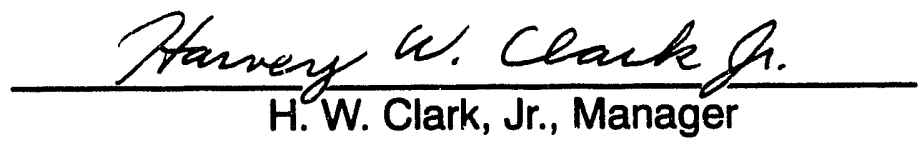

Radiation Science Section

This Document is UNCLASSIFIED

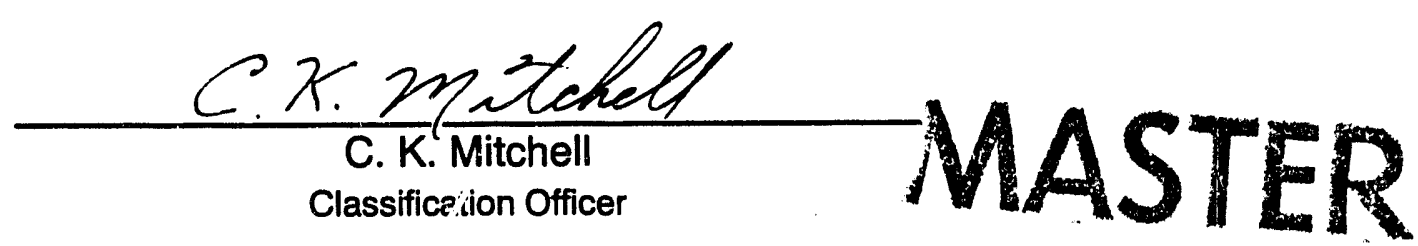

This work was performed by EG\&G/EM for the United Sta! es Department of Energy and the United States Nuclear Regulatory Commisssion under Contract Number DE-AC08-93NV11265. 


\begin{abstract}
An aerial radiological survey was conducted over the Fort Calhoun Nuclear Power Plant in Fort Calhoun, Nebraska, during the period June 19 through June 28, 1993. The survey was conducted at an altitude of 150 feet (46 meters) over a 25-scuare-mile (65-square-kilometer) area centered on the power station. The purpose of the survey was to document the terrestrial gamma radiation environment of the Fort Calhoun Nuclear Power Plant and surrounding area.
\end{abstract}

The results of the aerial survey are reported as inferred gamma radiation exposure rates at 1 meter above ground level in the form of a contour map. Outside the plant boundary, exposure rates were found to vary between 6 and 12 microroentgens per hour and were attributed to naturally-occurring uranium, thorium, and potassium.

The aerial data were compared to ground-based benchmark exposure rate measurements and radionuclide assays of soil samples obtained within the survey boundary. The ground-based measurements were found to be in good agreement with those inferred from the aerial measuring system.

A previous survey was conducted on August 9 and 10,1972, before the plant began operation. Exposure rates measured in both surveys were consistent with normal terrestrial background. 


\section{CONTENTS}

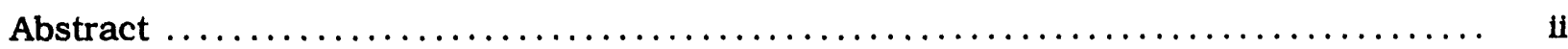

\section{Sections}

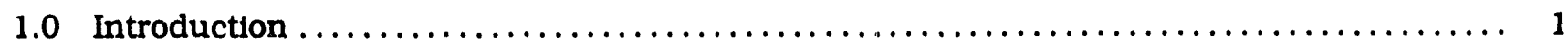

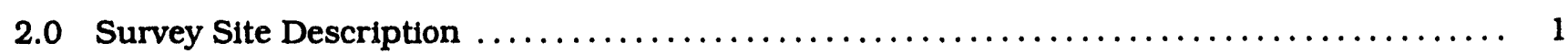

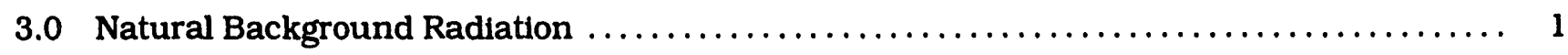

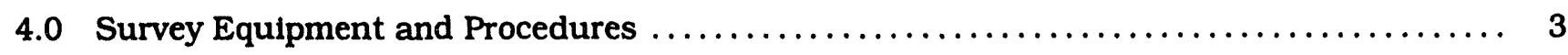

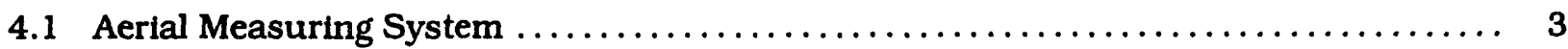

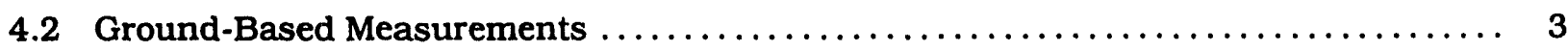

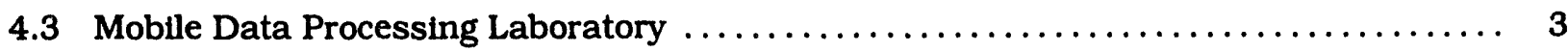

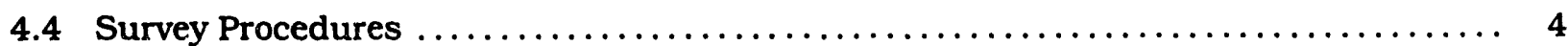

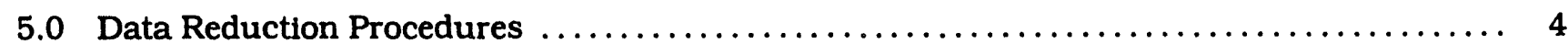

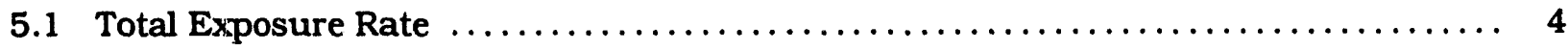

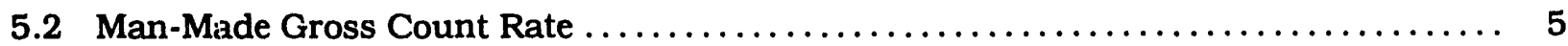

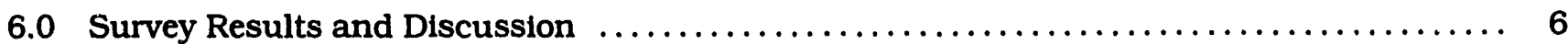

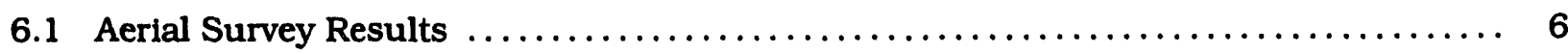

6.2 Ground-Based Measurement Results $\ldots \ldots \ldots \ldots \ldots \ldots \ldots \ldots \ldots \ldots \ldots \ldots \ldots$

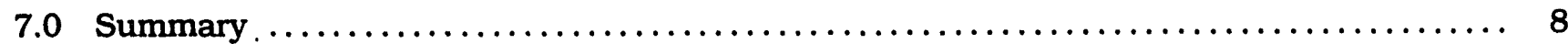

\section{Figures}

1 Aerial Photograph of the Fort Calhoun Nuclear Power Plant and Surrounding Area ...... 2

2 MBB BO-105 Helicopter with Detector Pods $\ldots \ldots \ldots \ldots \ldots \ldots \ldots \ldots \ldots \ldots \ldots \ldots$

3 Mobile Computer Processing Laboratory $\ldots \ldots \ldots \ldots \ldots \ldots \ldots \ldots \ldots \ldots \ldots \ldots \ldots \ldots$

4 Terrestrial Gamma Exposure Rate Contour Map $\ldots \ldots \ldots \ldots \ldots \ldots \ldots \ldots \ldots \ldots \ldots \ldots$

5 Typical Background Gamma Energy Spectrum $\ldots \ldots \ldots \ldots \ldots \ldots \ldots \ldots \ldots \ldots \ldots \ldots, 8$

6 Net Gamma Energy Spectrum over Reactor $\ldots \ldots \ldots \ldots \ldots \ldots \ldots \ldots \ldots \ldots \ldots \ldots \ldots$

\section{Tables}

1 Exposure Rates from Aerial and Ground-Based Measurements $\ldots \ldots \ldots \ldots \ldots \ldots \ldots \ldots \quad 8$

2 Radionuclide Assay of Soil Samples $\ldots \ldots \ldots \ldots \ldots \ldots \ldots \ldots \ldots \ldots \ldots \ldots \ldots \ldots \ldots \ldots$

\section{Appendix}

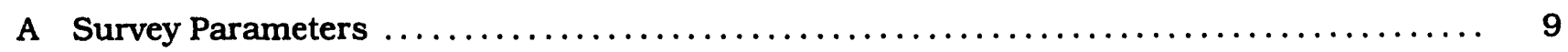

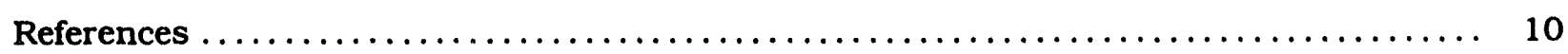




\subsection{INTRODUCTION}

An aerial radiological survey of the Fort Calhoun Nuclear Power Plant and surrounding area in Fort Calhoun, Nebraska, was conducted during the period June 19 through June 28, 1993, at the request of the United States Nuclear Regulatory Commission (NRC). The survey was performed using the aerial measuring system (AMS), operated by EG\&G Energy Measurements, Inc. (EG\&G/EM) for the United States Department of Energy (DOE). ${ }^{1}$ EG\&G/EM routinely conducts aerial surveys for DOE, NRC, and other government agencies as part of an ongoing, nationwide program to map and document the radiological conditions at various nuclear sites. Aerial radiological surveys have been effective in detecting regions of enhanced radiation, determining average ground-level exposure rates, and identifying specific radionuclides associated with regions of anomalous radiation levels.

The Fort Calhoun Nuclear Power Plant is owned by the Omaha Public Power District. The power plant contains a Combustion Engineering, Inc., pressurzed water reactor (PWR) capable of producing net electrical power of 505 megawatts. The power plant was constructed in 1968 and began serving the local communities in 1973. It is situated on 660 acres (267 hectares) on the west bank of the Missouri River, about 6 miles north of the town of Fort Calhoun, Nebraska.

The aerial survey was flown at an altitude of 150 feet (46 meters) using a grid pattern composed of parallel flight lines spaced 250 feet ( 76 meters) apart to cover the 25-square-mile (65-squarekilometer) area. The aerial data were used to derive exposure rates at 1 meter above ground level (AGL). In support of the aerial measurements, ground-based exposure rate measurements and soil samples were obtained from various benchmark sites identified by the aerial survey to contain only natural gamma activity. Radionuclide assay of the soil samples was performed to determine radioisotopic concentrations. Oblique aerial photographs of the Fort Calhoun Nuclear Power Plant were also obtained in conjunction with the survey.

\subsection{SURVEY SITE DESCRIPTION}

The Fort Calhoun Nuclear Power Plant is located in Washington County about 6 miles north of the town of Fort Calhoun, Nebraska. Presented in Figure 1 is a large-scele aerial photograph (June 1993) of the power plant and surrounding area. The survey boundary, outlined in Figure 1 , encompasses a 25-square-mile (65-square-kilometer) area centered on the power plant. The area surrounding the reactor consists of sparsely populated, rolling hills used primarily for farming.

\subsection{NATURAL BACKGROUND RADIATION}

Natural background radiation originates from radioactive nuclides which are present in various low-level concentrations in the earth and atmosphere as well as cosmic rays entering the earth's atmosphere from outer space. Terrestrial radiation, which originates primarily from the uranium decay chain, thorium decay chain, and radioactive potassium, is detected at the surface of the earth. The exposure rates from terrestrial radionuclides are dependent on the composition of soil and bedrock near the point of interest. In addition to the above-mentioned sources of natural radiation, cesium- 137 ( $\left.{ }^{137} \mathrm{Cs}\right)$, a product of nuclear fission, is present in trace quantities worldwide from fallout due to aboveground nuclear tests conducted until the early 1960 s. Exposure rates due to ${ }^{137} \mathrm{Cs}$ in the environment are typically less than $1 \mu \mathrm{R} / \mathrm{h} .^{2}$

Radon gas, a by-product in the decay chain of both uranium and thorium, diffuses through the soil into the atmosphere and contributes to the radiation levels near the surface of the earth. The radon concentration depends on several factors including meteorological conditions, mineral compositions, and permeability of the soll. Airborne radiation from radon and its decay products typically contributes from $1 \%$ to $10 \%$ to the natural background radiation.

Cosmic rays, high energy radiation originating from outer space, also contribute to the levels of natural background radiation. The cosmic rays from outer space shower the earth with a nearly constant flux of radiation which interacts with 


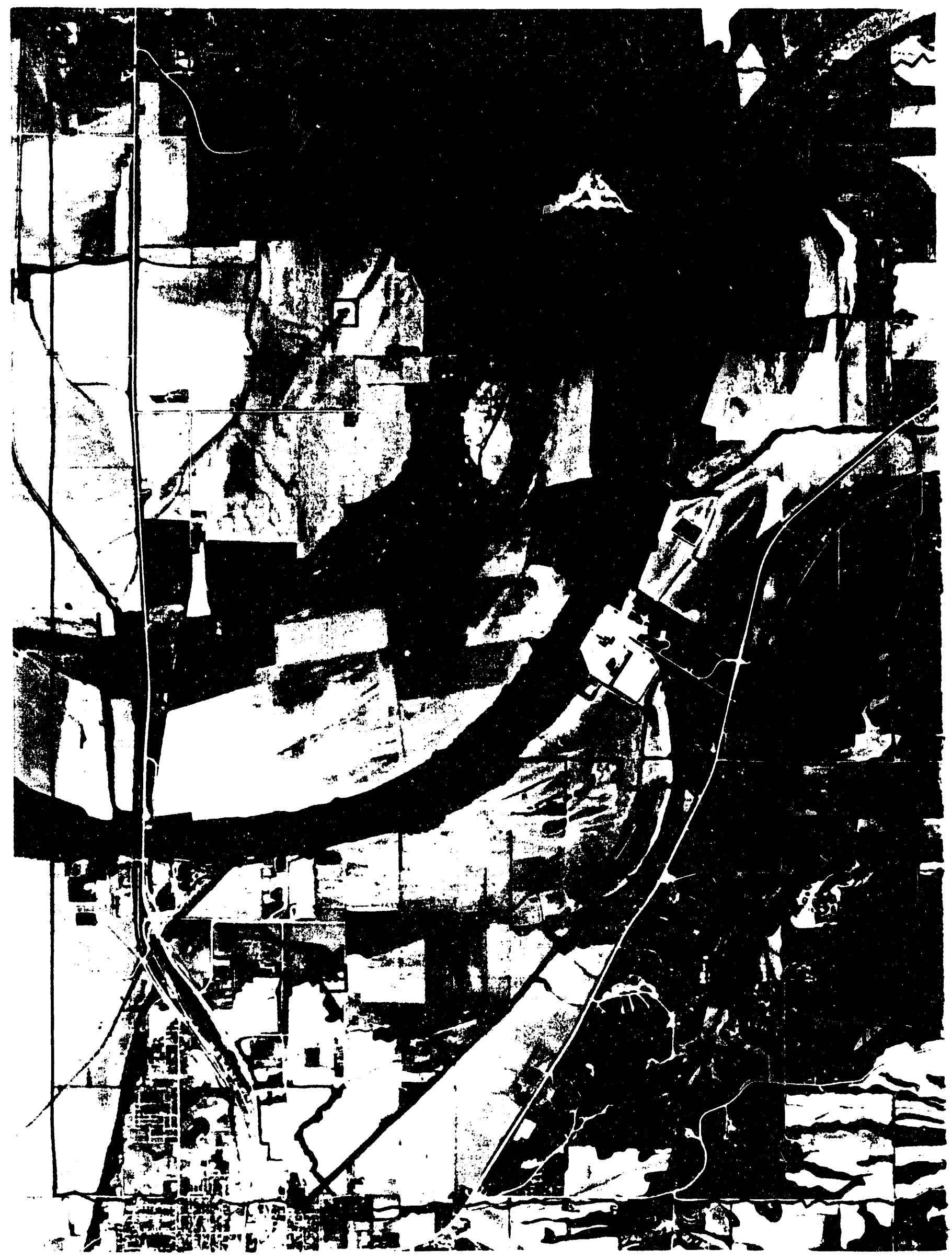




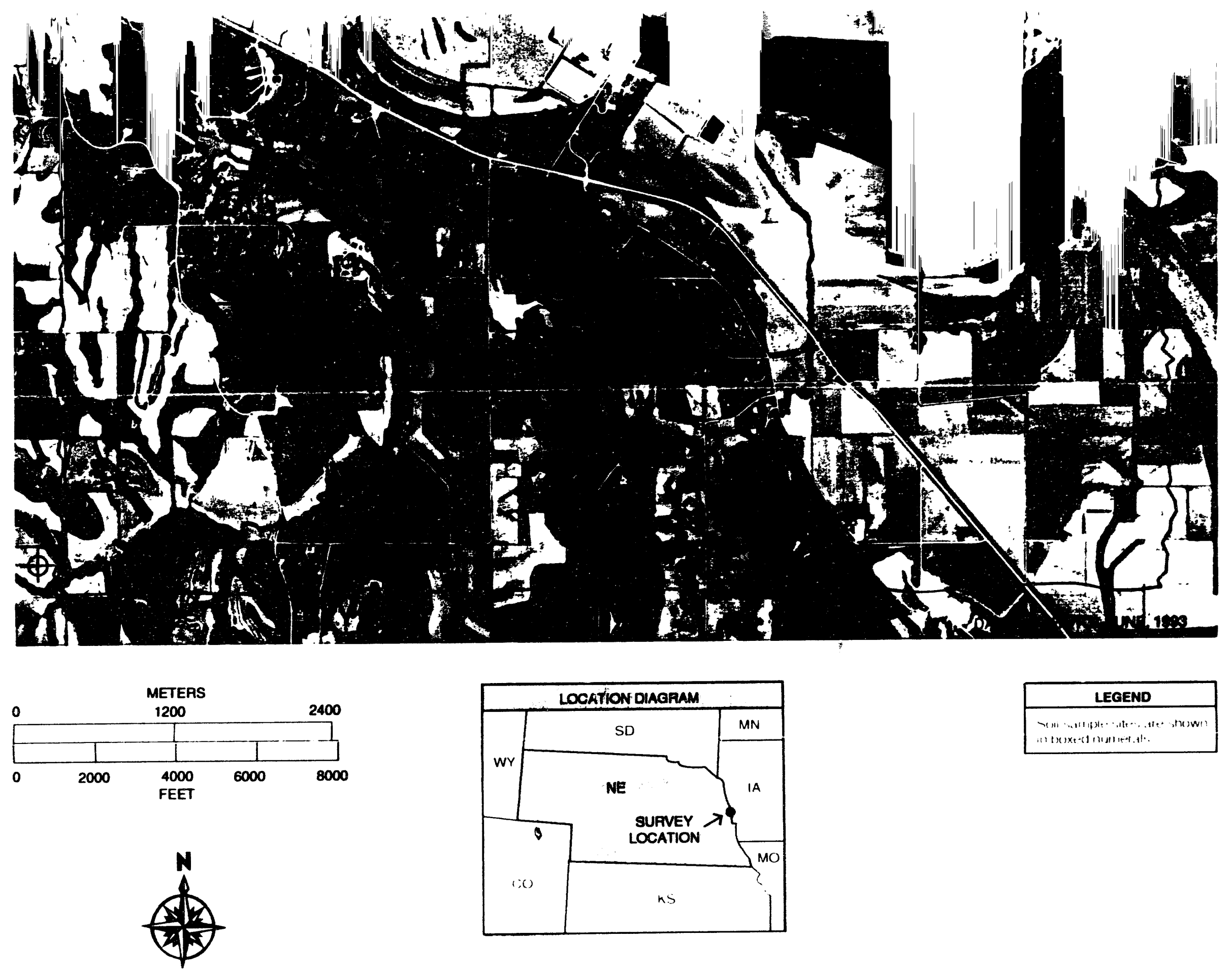

FIGURE 1. AERIAL PHOTOGRAPH OF THE FORT CALHOUN NUCLEAR POWER PLANT AND SURROUNDING AREA 
elements in the earth's atmosphere and soll producing an additional source of background activity. Radiation levels due to cosmic rays vary with altitude and geomagnetic latitude. Typical values range from $3.3 \mu \mathrm{R} / \mathrm{h}$ at sea level to 12 $\mu \mathrm{R} / \mathrm{h}$ (up to $100 \mathrm{mrem} / \mathrm{yr}$ ) at elevations of 10,000 feet (3 kilometers). ${ }^{3}$ For the Fort Calhoun, Nebraska, area the cosmic ray contribution is approximately $3.9 \mu \mathrm{R} / \mathrm{h}$.

\subsection{SURVEY EQUIPMENT AND PROCEDURES}

\subsection{Aerial Measuring System}

The low altitude aerial survey was flown using a Messerschmitt-Bolkow-Blohm (MBB BO-105) helicopter shown is Figure 2. The twin-engine helicopter was outfitted with a Radiation and Environmental Data Acquisition and Recorder System IV (REDAR IV) and two gamma detection pods which were mounted on the sides of the skid rack on the helicopter. Each pod housed four 2- $\times$ 4- $\times 16$-inch log-type thallium-activated sodium lodide, $\mathrm{Nal}(\mathrm{T} l)$, gamma ray detectors. The energy response of the detector array was calibrated using the $60-\mathrm{keV}$ gamma rays from americium-241 $\left({ }^{241} \mathrm{Am}\right)$ and the $1,274-\mathrm{keV}$ gamma rays from sodium-22 $\left({ }^{22} \mathrm{Na}\right)$. At an altitude of 150 feet ( 46 meters), the AMS full detector arrays give accurate terrestrial gamma spectral information up to $50 \mu \mathrm{R} / \mathrm{h}$. The dynamic range of AMS is extended to $400 \mu R / h$ through the use of a single 2- $\times 4-\times 16$-inch detector.

Data acquisition was performed using REDAP IV, a rack-mounted portable multimicroprocessor real-time analysis system. The system was

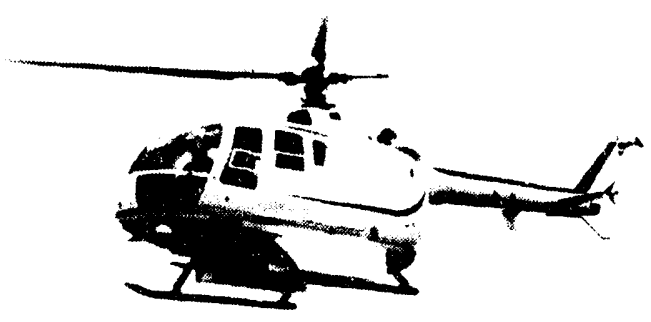

FIGURE 2. MBB B0-105 HELICOPTER WITH DETECTOR PODS designed to operate in adverse conditions such as those encountered in helicopter or fixed-wing platforms. The REDAR IV system recorded on magnetic tape live-time data from the detector array, ambient temperature and barometric pressure sensors, radar altimeter, and the hellcopter positioning information. The REDAR IV system was also equipped with the capability for real-time inspection of gamma energy spectra by a video display.

Aircraft positioning was established using a Real-time Differential Global Positioning System (RDGPS) and a radar altimeter. A GPS base station transmitted a position correction to a GPS unit housed in the helicopter. The transmitted correction received by the helicopter's GPS unit minimized the position uncertainty to \pm 15 feet (5 meters). The position information was recorded on magnetic tape and directed into the steering indicator which the pllot used to guide the aircraft along a predetermined set of flight lines. Similarly, the radar altimeter determines the helicopter's altitude. For altitudes up to 300 meters, the precision of this system as stated by the manufacturer is \pm 0.6 meters or $2 \%$, whichever is greater.

\subsection{Ground-Based Measurements}

Total exposure rates and soll samples were obtained from four ground-based benchmark sites for veriflcation of the aerial measurements. The four sites, designated in Figure 1, were identifled by the aerial survey as having only natural background radiation. At each site, total exposure rates were measured with a gamma ionization chamber and four soll samples were taken for laboratory analysis. Soll sample analysis was performed at the EG\&G / EM Santa Barbara Laboratory in accordance with previously outlined procedures. 4

\subsection{Mobile Data Processing Laboratory}

The operations base for the survey was the Sky Harbor Air Service Airport located approximately 20 miles (32 kilometers) south of the Fort Calhoun Nuclear Power Plant in Omaha, Nebraska. The Radiation and Environmental Data Analyzer and Computer (REDAC) system, 
a moblle computer laboratory for analysis of the aerial survey data shown in Figure 3, was located at the operations base. The REDAC system consists of a Data General MV-7800XP computer with 4 megabytes of memory, a 2.8-gigabyte SCSI disk for mass storage, an $8 \mathrm{~mm}$ tape drive, a Gic-tape drive, 9-track tape drives for data transfer and archiving, a 36-inchwide plotter for data contouring, a laser printer, and two IBM personal computers for terminal emulation.

The REDAC system utilizes an extensive software library for analysis of the pre- and postflight REDAR IV and detector system checks, and provides on-site preliminary analysis of the aerial measurements on a flight-by-flight basis.

\subsection{Survey Procedures}

The aerial survey over the Fort Calhoun Nuclear Power Plant and surrounding area was conducted according to standardized procedures which will be discussed only briefly in this section. ${ }^{1.5} \mathrm{~A}$ perimeter of the survey area was flown utilizing roads easily identifiable on a largescale aerial photograph. Intersections of roadways and landmarks were noted by flightcrew personnel for future use in scaling the radiation contour data to aerial photographs.

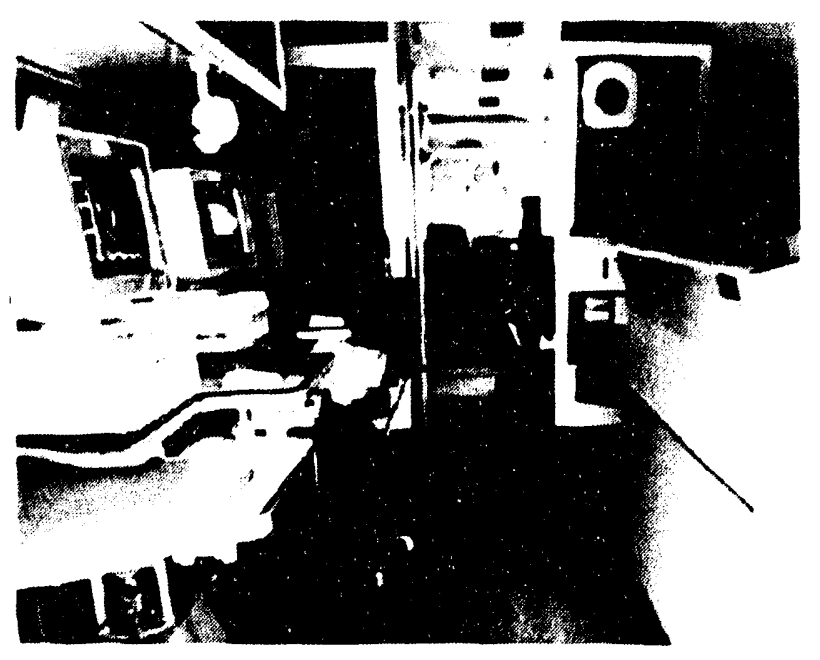

FIGURE 3. MOBILE COMPUTER PROCESSING LABORATORY
Altitude profles were flown over designated water and land test lines. An altitude proflle consisted of several flights over a test line at nominal altitudes ranging from 150 feet (46 meters) to 3,000 feet ( 914 meters). The water test line and land test line were flown at the beginning and end of each flight. The water test line was flown using a section of the Missouri River east of the survey site. Data accumulated during the water test line proflle were used to determine the non-terrestrial background radiation which originates from airborne radon, the helicopter and detector system, and cosmic rays. The water test line was flown at the survey altitude during each survey flight to monitor fluctuations in the radon concentration. For the land test line, a section of a road south of the survey area was chosen. The terrestrial data from the land test line profile, corrected for the non-terrestrial background, were used to derive an air attenuation coefficient.

The aerial survey covered an area of 25 square miles (65 square kilometers), as outlined in Figure 1. One hundred and six east-west flight lines, spaced 250 feet (76 meters) apart, were flown at an altitude of 150 feet (46 meters) AGL. All flights were flown at an average ground speed of 70 knots ( 36 meters/second). The aerial survey over the Fort Calhoun Nuclear Power Plant and surrounding area was completed in ten flights over a period of ten days.

\subsection{DATA REDUCTION PROCEDURES}

\subsection{Total Exposure Rate}

A contour map of the total gamma radiation exposure rates in $\mu \mathrm{R} / \mathrm{h}$ at 1 meter AGL was prepared from the aerial data. The total exposure rate contour map was derived from the gross count rates and aircraft positioning coordinates recorded during the survey flights. The gross count rate data were determined from the integrated yield of all gamma activity within the energy range 38 through $3,026 \mathrm{keV}$. Gross count rates in counts per second (cps) obtained from the aerial survey were converted to exposure rates in $\mu \mathrm{R} / \mathrm{h}$ at 1 meter AGL according to 


$$
E R(\mu \mathrm{R} / \mathrm{h})=\frac{G C-B}{889_{c p s /(\mu R / h)}} e^{(.4-150) \cdot C}
$$

where

$$
\begin{aligned}
G C= & \begin{array}{l}
\text { gross count rate at survey altitude } \\
\text { (cps) }
\end{array} \\
B= & \text { background count rate at survey } \\
& \text { altitude (cps) } \\
A= & \text { survey altitude (feet) } \\
C= & \text { air attenuation coefficient }
\end{aligned}
$$

An air attenuation coefficient having a value of 0.002260 feet $^{-1}$ was determined empirically from the background-subtracted gross count data obtained from the altitude profile over the land test line. The gross count rates were converted to exposure rates using a conversion factor of 889 counts $/$ second $/ \mu R / h$ at 150 feet $(46$ meters) derived from data obtained at the Calvert County calibration range near Washington, D.C. 6 The reported exposure rates include a contribution from cosmic rays of $3.9 \mu R / h$.

The total gamma exposure rates measured using the AMS represent average exposure rates for gamma rays emitted from nuclides distributed over a large area on the ground. The averaging process is a function of the angular response of the detector system and the motion of the aircraft during data accumulation. In general, twothirds of the detected gamma rays emanate from a circular area having a radius which is nearly the same as the detector altitude above ground level.

\subsection{Man-Made Gross Count Rate}

The aerial survey data. were also used to deter$m^{\prime}$ ne the location of man-made radionuclides. The man-made gross count (MMGC) is defined as the fraction of the gross counts which is directly attributed to gamma rays emitted from man-made radionuclides. In general, the detection of man-made radioisotopes can be found from increases in the gross count rates. However, slight changes in the gross count rates are not considered adequate reason to suspect a man-made radioisotope. Slight variations in the gross count rates can be attributed to fluctuations in the geology as well as changes in the ground vegetation coverage.

A more conclusive approach for detecting manmade radioisotopes involves a comparison of gross counts from various regions of the gamma energy spectrum. In particular, the ratio of spectral intensities from different regions of the gamma spectrum will remain nearly constant when only background radiation is present. Although this procedure can be applied to any region of the gamma spectrum, the most common practice is to place into the source window all counts below $1,394 \mathrm{keV}$, i.e., where most man-made radiation occurs, and to place into the background window all counts above 1,394 $\mathrm{keV}$. The MMGC algorithm has been found to be sensitive to low levels of man-made radiation, l.e., $<1 \mu \mathrm{R} / \mathrm{h}$, even in the presence of large variations in the natural background.

The MMGC rate can be expressed analytically in terms of the integrated count rates in specific spectral energy windows (in $\mathrm{keV}$ ) from the gamma energy spectrum

$$
\begin{aligned}
\text { MMGC } & =\sum_{E=38 \mathrm{keV}}^{1394 \mathrm{keV}} \text { Counts }_{E} \\
& -K \cdot \sum_{E=1394 \mathrm{keV}}^{3026 \mathrm{keV}} \text { Counts }_{E}
\end{aligned}
$$

where

$$
\sum_{E=38 \mathrm{keV}}^{1394 \mathrm{keV}} \text { Counts }_{E}=\begin{aligned}
& \text { integral count rate in the } \\
& \text { energy window from } \\
& 38-1,394 \mathrm{keV}
\end{aligned}
$$

$$
\sum_{E=1394 \mathrm{keV}}^{3026 \mathrm{keV}} \text { Counts }_{E}=\begin{aligned}
& \text { integral count rate in the } \\
& \text { energy window from } \\
& 1,394-3,026 \mathrm{keV}
\end{aligned}
$$


and

$$
K=\sum_{E=38 \mathrm{keV}}^{1394 \mathrm{keV}} \text { Counts }_{E} / \sum_{E=1394 \mathrm{keV}}^{3026 \mathrm{keV}} \text { Counts }_{E}
$$

The constant, $K$, was obtained from the summation spectrum composed of the gamma spectra acquired over a region of the survey area which was identifled to contain only gamma activity from naturally-occurring radionuclides. The resultant MMGC will yield an average value approximately equal to zero for areas containing only natural radionuclides and a value greater than zero for areas containing man-made radionuclides. Identification of the radionuclides responsible for anomalous behavior in the manmade gross count data can be made from the corresponding gamma energy spectrum.

\subsection{SURVEY RESULTS AND DISCUSSION}

\subsection{Aerial Survey Results}

Presented in Figure 4 is a contour map showing the total gamma exposure rates $(\mu \mathrm{R} / \mathrm{h})$ at 1 meter AGL inferred from the aerial data at the Fort Calhoun Nuclear Power Plant and surrounding area. The contour map is superimposed on a large-scale aerial photograph. Exposure rates were found to vary from 6 to $12 \mu \mathrm{R} / \mathrm{h}$ outside the plant boundary and to be approximately $11.5 \mu \mathrm{R} / \mathrm{h}$ directly over the power plant. Included in the exposure rate data is a cosmic ray contribution of $3.9 \mu R / h$. During the survey period, the operating level of the power plant varied from $13 \%$ to $100 \%$. The plant was operating at $13 \%$ the day the flight lines over the plant were flown. The exposure rates measured at the site are typical of normal terrestrial background for the surrounding area.

A typical gamma energy spectrum obtained outside the plant boundary is presented in Figure 5. The most prominent gamma peaks are identifled as those from naturally-occurring radionuclides from the uranium and thorium decay chains as well as radioactive potassium-40 $\left({ }^{40} \mathrm{~K}\right)$.

A net gamma energy spectrum obtained over the plant is presented in Figure 6. Identifiable manmade peaks observed were at 1,173 and 1,333 $\mathrm{keV}$, associated with cobalt $-60\left({ }^{60} \mathrm{Co}\right)$, an activation product, and at $662 \mathrm{keV}$, associated with ${ }^{137} \mathrm{Cs}$, a fission product. These peaks are normal with the type of power reactor utilized at Fort Calhoun.

In addition to the exposure rate contours (Figure 4), an MMGC contour map was also produced. The only significant gamma activity shown by the MMGC extraction was directly over the plant. As plant activity is adequately described by the exposure rate contour, the MMGC contour is not presented in this report.

\subsection{Ground-Based Measurement Results}

Identified in Figure 1 are the locations of the four ground-based measurements. Total exposure rates and soll samples were obtained at four benchmark sites for comparison and verification of the aerial measurements. ${ }^{7}$ A comparison of the exposure rates from the aerial and ground-based measurements is given in Table 1. The soil analysis estimates include an additional 3.9-4.0 $\mu \mathrm{R} / \mathrm{h}$ cosmic contribution and the inferred aerial results include an additional 3.9 $\mu R / h$ cosmic contribution. The results from the aerlal and ground-based measurements are essentially in agreement.

Presented in Table 2 are the results of the radionuclide assay of the soil samples from the four benchmark sites. Soil sample results represent those from averages of four closely spaced samples obtained from each site. In addition to the naturally-occurring isotopes from the decay chains (uranium and thorium) and ${ }^{40} \mathrm{~K}$, all sampling sites exhibited a presence of ${ }^{137} \mathrm{Cs}$. Cesium-137 is present in the environment as a result of worldwide fallout from aboveground nuclear tests conducted until the early 1960 s. The level of ${ }^{137} \mathrm{Cs}$ activity measured at the benchmark sites is typical of that measured at several locations within the continental United States. ${ }^{2}$ 


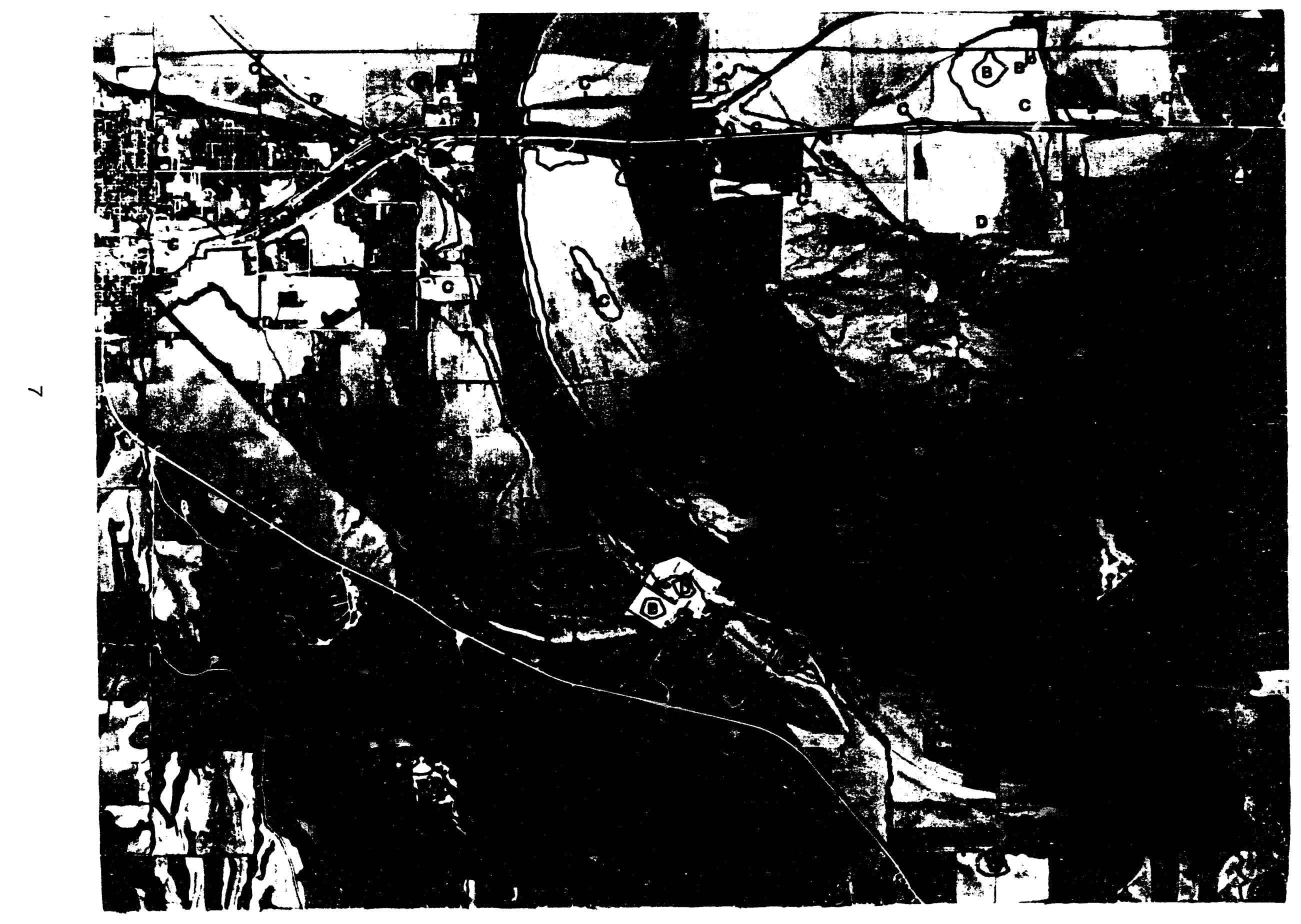



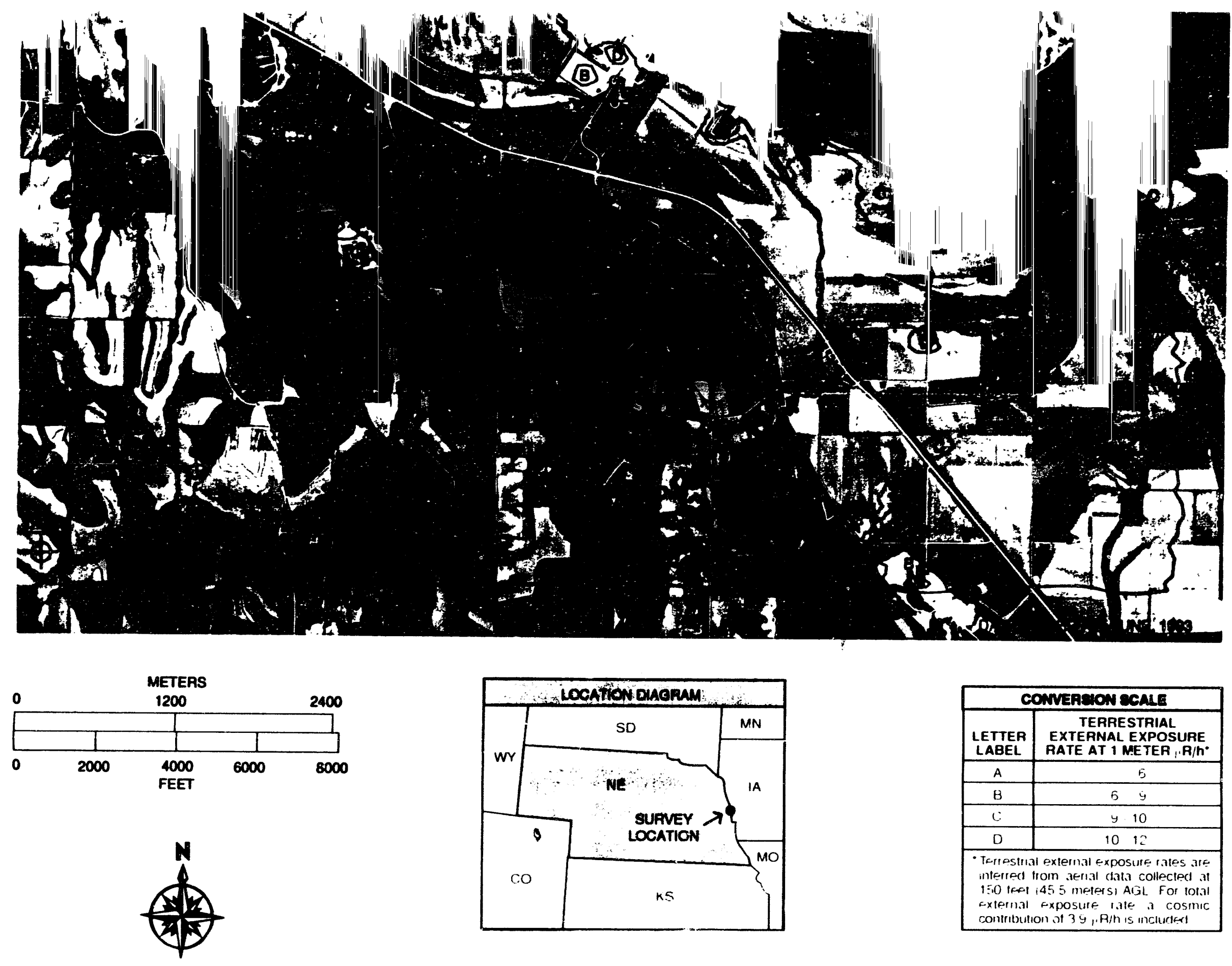


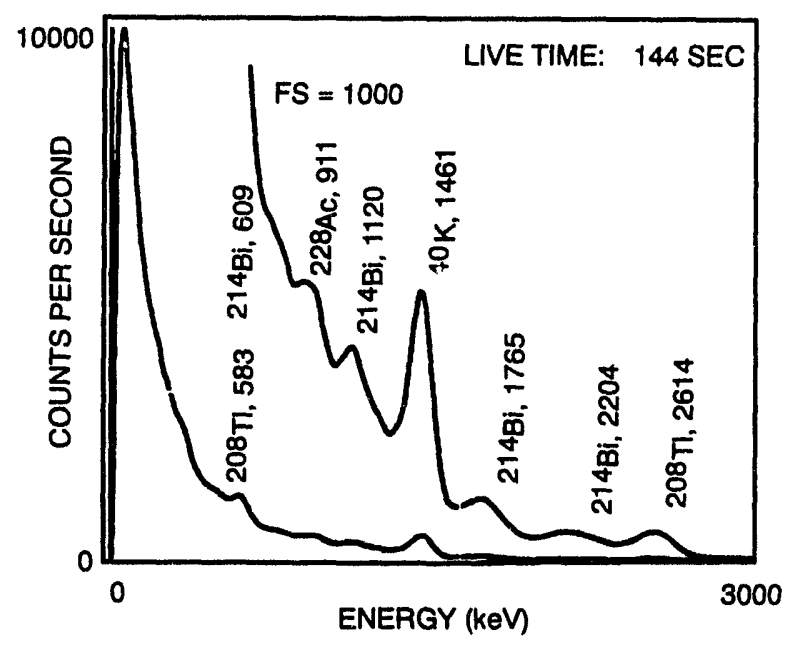

FIGURE 5. TYPICAL BACKGROUND GAMMA ENERGY SPECTRUM

\subsection{SUMMARY}

An aerial radiological survey of the Fort Calhoun Nuclear Power Plant was conducted during the period June 19 through June 28, 1993. An area of 25 square miles ( 65 square kilometers) was

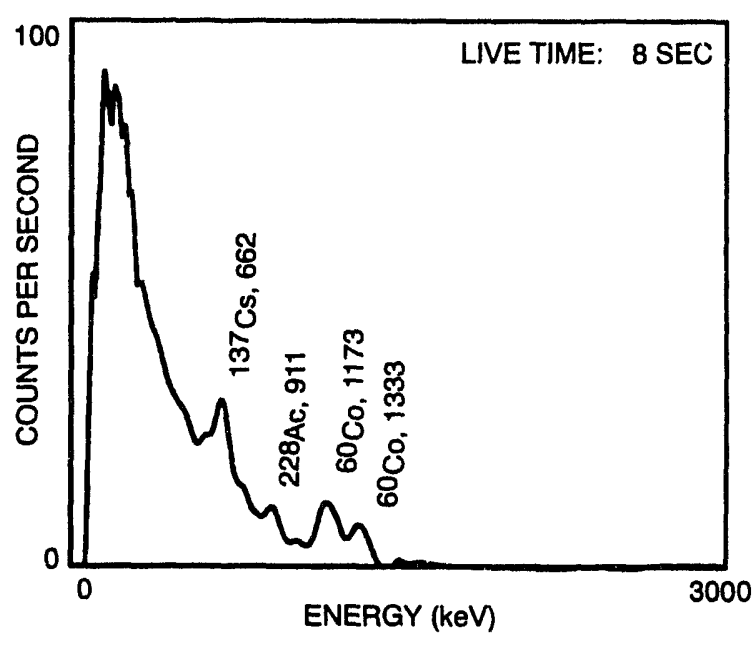

FIGURE 6. NET GAMMA ENERGY SPECTRUM OVER REACTOR

surveyed at an altitude of 150 feet (46 meters) using a grid pattern consisting of nominally parallel flight lines. The typical terrestrial gamma radiation exposure rate was found to vary from 6 to $12 \mu \mathrm{R} / \mathrm{h}$. No significant man-made radioactivity was detected outside the plant boundary.

\begin{tabular}{|c|c|c|c|}
\hline \multicolumn{3}{|c|}{ Table 1. Exposure Rates from Aerial and Ground-Based Measurements ${ }^{\mathrm{a}}$} \\
\hline Site & Soil Analysis $^{\mathrm{b}}$ & Ion Chamberc & Aerial Survey $^{-4}$ \\
\hline 1 & $10.9 \pm 0.5$ & $10.0 \pm 0.5$ & $10.0 \pm 0.5$ \\
2 & $10.2 \pm 0.4$ & $9.9 \pm 0.5$ & $10.5 \pm 0.5$ \\
3 & $10.9 \pm 0.5$ & $10.0 \pm 0.5$ & $10.3 \pm 0.5$ \\
4 & $11.3 \pm 0.7$ & $10.5 \pm 0.5$ & $10.1 \pm 0.5$ \\
\hline
\end{tabular}

a Exposure rate $(\mu \mathrm{R} / \mathrm{h}$ at 1 meter $\mathrm{AGL}) \pm$ the standard deviation.

${ }^{b}$ Calculations include a cosmic ray contribution of $3.9-4.0 \mu \mathrm{R} / \mathrm{h}$ and a molsture correction of the form $1 /(1+\mathrm{m})$.

c Reuter-Stokes Model Number RSS-112, Serial Number G-003.

\begin{tabular}{|c|c|c|c|c|c|}
\hline \multicolumn{7}{|c|}{ Table 2. Radionuclide Assay of Soil Samples } \\
\hline Site & $\%$ Moisture & $\begin{array}{l}{ }_{226} \text { Ra } \\
(\mathrm{pCi} / \mathrm{g})\end{array}$ & $\begin{array}{c}\text { 232Th }_{(\mathrm{PCl} / \mathrm{g})} \\
137 \mathrm{Cs} \\
(\mathrm{pCl} / \mathrm{g})\end{array}$ & $\begin{array}{c}40 \mathrm{~K} \\
(\mathrm{pCi} / \mathrm{g})\end{array}$ \\
\hline 1 & $21 \pm 2$ & $1.1 \pm 0.1$ & $1.1 \pm 0.1$ & $0.10 \pm 0.08$ & $17.5 \pm 0.3$ \\
2 & $17 \pm 1$ & $0.9 \pm 0.1$ & $0.86 \pm 0.4$ & $0.4 \pm 0.2$ & $17.8 \pm 0.4$ \\
3 & $18 \pm 2$ & $1.0 \pm 0.1$ & $1.0 \pm 0.2$ & $0.27 \pm 0.07$ & $19.1 \pm 0.07$ \\
4 & $21 \pm 2$ & $1.1 \pm 0.1$ & $1.1 \pm 0.1$ & $0.4 \pm 0.2$ & $19.0 \pm 2.0$ \\
\hline
\end{tabular}


APPENDIXA

\section{SURVEY PARAMETERS}

Survey Site:

Survey Dates:

Survey Coverage:

Project Scientist:

Survey Aircraft:

Acquisition System:

Detector Array 1:

Detector Array 2:

Lines Surveyed:

Line Direction

Survey Altitude:

Line Spacing:

Navigation System:

Average Ground Speed:
Fort Calhoun Nuclear Power Plant

Fort Calhoun, Nebraska

June 19-28, 1993

$25 \mathrm{mi}^{2}\left(65 \mathrm{~km}^{2}\right)$

K.A. McCall

MBB BO-105 helicopter

REDAR IV

Eight 2- $\times 4-\times 16-$ in $\mathrm{NaI}(\mathrm{Tl})$ detectors

One 2- $\times 4-\times 16-$ in $\mathrm{NaI}(\mathrm{Tl})$ detector

106

East-West

$150 \mathrm{ft}(46 \mathrm{~m})$

$250 \mathrm{ft}(76 \mathrm{~m})$

RDGPS

70 knots ( $36 \mathrm{~m} / \mathrm{s})$ 


\section{REFERENCES}

1. Jobst, J.E. "The Aerial Measuring System Program." Nuclear Safety, March/April 1979, 20:136-147.

2. Mohr, R.A. and L.A. Franks. Compllation of Cs-137 Concentrations at Selected Sites in the Continental United States, Report No. EGG-1183-2437, S-724-R. EG\&G/EM, Santa Barbara, California, 1982.

3. Klement, A.W., et al. Estimate of Ionizing Radiation Doses in the United States 1960-2000, EPA Report ORD/CD72-1. EPA, Washington, D.C., 1972.

4. Mohr, R.A., A.E. Fritzsche, and L.A. Franks. Ground Survey Procedures, Report No. EGG-1 183-2339, S-635-R. EG\&G/EM, Santa Barbara, Callfornia, 1976.

5. Boyns, P.K. The Aerial Radiological Measuring System (ARMS): System, Procedures and Sensitivity, Report No. EGG-1183-1691. EG\&G/EM, Las Vegas, Nevada, 1976.

6. Mohr, R.A. Ground Truth Measurements at the Calvert County, Maryland Test Line, Report No. EGG-10282-2066. EG\&G/EM, Santa Barbara, California, 1985.

7. Mohr, R.A. Ft. Calhoun Survey Ground Truth Data, Memorandum RM-93-171. EG\&G/EM, Santa Barbara, California, 1993. 


\section{DISTRIBUTION}

NRC/HQ

E. D. Weinstein

(1)

NRC/REGION IV

E. F. Bates

(7)

(1)

(1)

L. E. Gordon-Hagerty

O.W. Taylor

DOE/HQ

OSTI
DOE/NV

M.R. Dockter
C.A. Santilli
T. D. Wiard

(1)

(1)

(2)

LBL

H. A. Wollenberg

(1)

\section{EG\&G/EM}

J. F. Doyle LVAO

K.A. McCall LVAO

G.R. Shipman WAMO

W.J. Tipton LVAO

P. H. Zavattaro LVAO

(1)

(1)

(1)

(1)

(1)

\section{LIBRARIES}

RSL

TIC
(30)

(1)

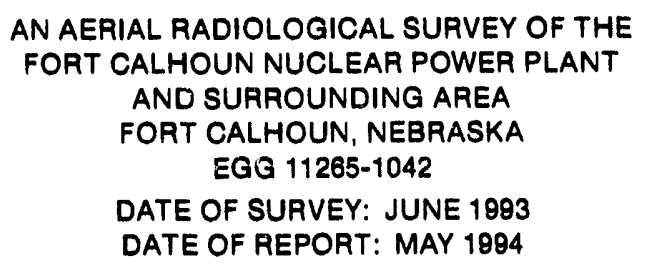



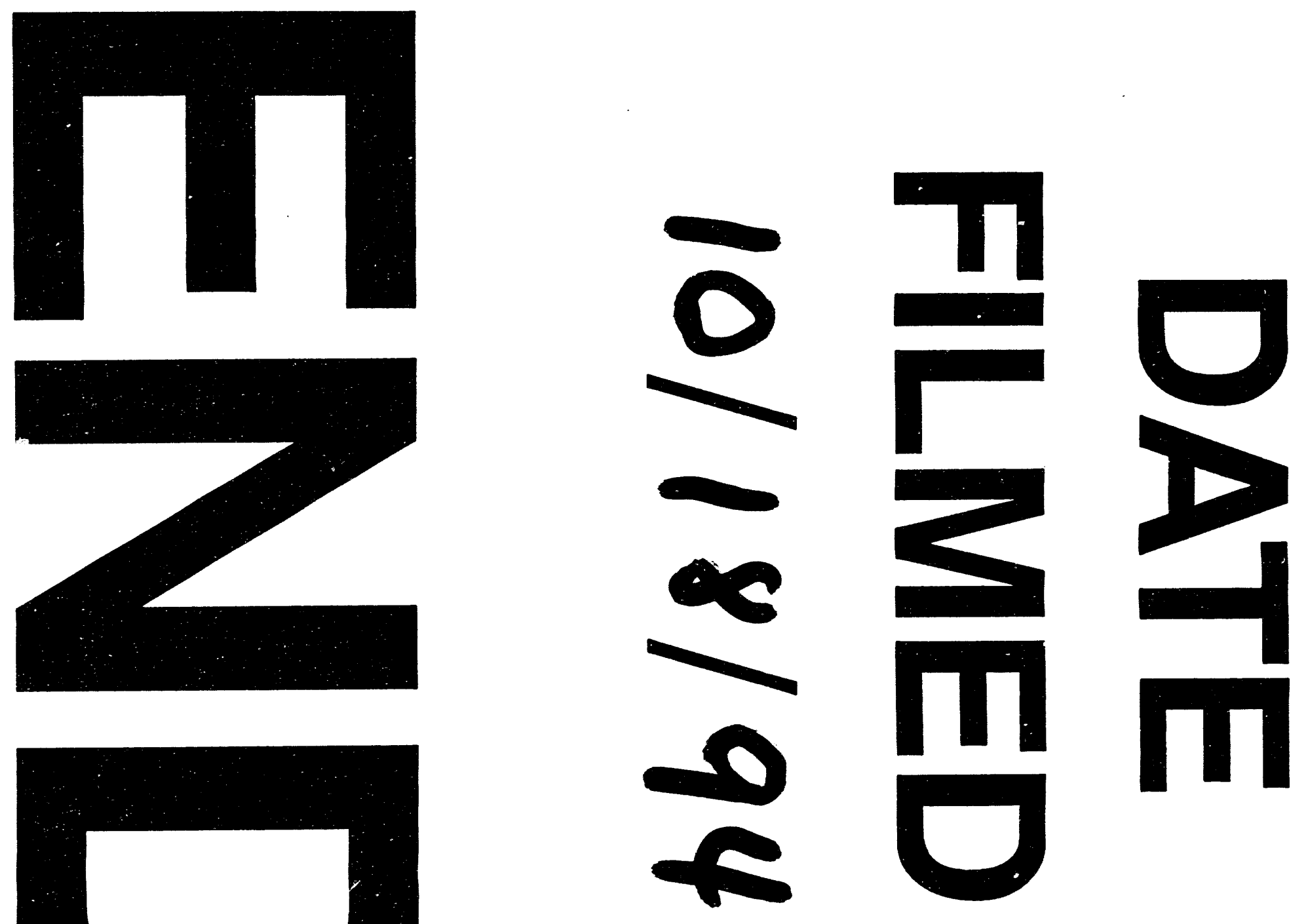
